If chapatti flour were to be enriched with vitamin $D$, as has been found to be feasible in Glasgow, ${ }^{27}$ Goans (whose intake of flour is low) would receive least benefit, but they appear to have satisfactory intakes already. Most chapatti flour was consumed by Sikhs and Hindus, whose intakes of vitamin $\mathrm{D}$ and serum $25-\mathrm{OHD}_{3}$ levels were low.

We thank Dr A Copeland, Dr J Jewkes, Mrs R Ma, and Dr A Paliwalla, for their help with taking blood samples, and, above all, the members of the families for their conscientious co-operation. This work was done during the tenure of a scholarship from the Science Research Council (SPH) and is now continuing with a grant from the Department of Health and Social Security. J L H O'R would like to acknowledge the help of the Wellcome Trust.

\section{References}

1 Dunningan, M G, et al, Scottish Medical fournal, 1962, 7, 159.

2 Preece, M A, et al, Lancet, 1973, 1, 907.

${ }^{3}$ Cooke, W T, et al, British Medical fournal, 1974, 2, 293.

4 Dent, C E, and Gupta, M M, Lancet, 1975, 2, 1057.

5 Swan, C H J, and Cooke, W T, Lancet, 1971, 2, 456.

6 Hodgkin, P, et al, Lancet, 1973, 2, 167.

7 Dent, C E, et al, Lancet, 1973, 1, 1282
${ }^{8}$ Holmes, A M, et al, Quarterly fournal of Medicine, 1973, 42, 125.

${ }^{9}$ Dent, C E, and Smith, R, Quarterly fournal of Medicine, 1969, 38, 195.

10 Gupta, M M, Round, J M, and Stamp, T C B, Lancet, 1974, 1, 586.

11 Ford, J A, et al, British Medical fournal, 1972, 3, 446

12 Hunt, S P, Nutrition and Food Science, 1976, 43, 2.

13 Cohen, Y A, in Encyclopedia Britannica, 15th edn, vol 5, p 728. Chicago, Macropedia, 1974.

14 Marr, J W, World Review of Nutrition and Dietetics, 1971, 13, 105.

15 McCance, R A, and Widdowson, E M, The Composition of Foods, MRC Special Report Series No 297. London, HMSO, 1960.

16 Gopalan, C, Rama-Sashi, B V, and Balasubramanian, S C, Nutritive Value of Indian Foods. Hyderabad, National Institute of Nutrition, 1974.

17 Watt, B K, and Merrill, A L, Composition of Foods, Agriculture Handbook No 8. Washington, DC, US Department of Agriculture, 1963.

${ }^{18}$ Ministry of Agriculture, Fisheries and Food. Household Food Consumption and Expenditure, 1973, Annual Report of the National Food Survey Committee. London, HMSO, 1975.

19 Preece, M A, et al, Quarterly fournal of Medicine, 1975, 44, 575.

20 Balasubramanian, S L, and Gopalan, C, Diet Atlas of India. Hyderabad, National Institute of Nutrition, 1969.

${ }^{21}$ Mahar, J M, India: A Critical Bibliography. Arizona, University of Arizona Press, 1964.

22 Watney, P J M, et al, British Medical fournal, 1971, 2, 432.

${ }^{23}$ Department of Health and Social Security. Recommended Intakes of Nutrients for the United Kingdom. London, HMSO, 1969.

${ }^{24}$ Ford, J A, et al, British Medical fournal, 1972, 3, 446.

25 Wills, M R, et al, Lancet, 1972, 1, 771.

26 Vaishnava, H, and Rizvi, S N A, Lancet, 1973, 2, 622

27 Pietrek, J, et al, Lancet, 1976, 1, 1145.

28 Dunnigan, M G, et al, Scottish Medical fournal, 1975, 20, 217

\title{
Changed levels of endogenous sex steroids in women on oral contraceptives
}

\author{
J M KJELD, C M PUAH, G F JOPLIN
}

\section{Introduction}

The way that oral contraceptives act is still unknown, but they are thought to either inhibit gonadotrophin release or directly affect the ovaries and the genital tract. Oral contraceptives lower serum and urinary gonadotrophin levels, ${ }^{1}$ but there is conflicting evidence on whether they reduce oestradiol levels. ${ }^{2-5}$ Raised serum testosterone concentrations have been found in women taking oral contraceptives, ${ }^{36}{ }^{7}$ but there are no data on $5 \alpha-$ dihydrotestosterone, an androgen that is more than twice as potent as testosterone in some bioassays. ${ }^{8}$

Oral contraceptives are often given as long-term replacement therapy in young women with hypogonadism resulting from operations, such as ${ }^{90} \mathrm{Y}$ or ${ }^{198} \mathrm{Au}$ pituitary implantation for treatment of pituitary tumours. ${ }^{9}$

In a small group of healthy women we assessed the effects of oral contraceptives on serum levels of the main sex hormones and measured the simultaneous urinary excretion of the unconjugated hormone.

\section{Subjects and methods}

Nineteen healthy members of the hospital staff, aged 18-34, volunteered for this study. Ten women who were not taking any medication acted as controls; they were studied in the first 10 days of their menstrual cycle. The other nine had all been taking oral contraceptives for at least two months and were studied at various days from their last menstrual bleeding. Five women were taking Ovran (ethinyloestradiol $50 \mu \mathrm{g}$ and D-norgestrel $250 \mu \mathrm{g}$ ), two were taking Eugynon 50 (ethinyloestradiol $50 \mu \mathrm{g}$ and DL-norgestrel $500 \mu \mathrm{g}$ ), and two were taking Gynovlar 21 (ethinyloestradiol $50 \mu \mathrm{g}$ and norethisterone acetate $3 \mathrm{mg}$ ).
Endocrine Unit, Department of Medicine, Royal Postgraduate Medical School, Hammersmith Hospital, London W12 0HS

J M KJELD, MD, research fellow

C M PUAH, BSC, technical officer

$G$ F JOPLIN, PHD, FRCP, consultant physician and senior lecturer in clinical endocrinology 
Specimens-The women collected all urine passed between 8 am and $8 \mathrm{pm}$ on one day, keeping the urine refrigerated during the collection. They then made a second collection of urine passed between $8 \mathrm{pm}$ and 8 am the next morning. No preservatives were added to the urine samples, which were frozen immediately on reception and kept at $-20^{\circ} \mathrm{C}$ until assayed. Blood was withdrawn between 3 and $4 \mathrm{pm}$ on the day of the collection and at 9-10 am the next morning. Serum was separated from the blood clot within three hours of sampling and stored at $-20^{\circ} \mathrm{C}$ until assayed.

Assays-Serum and urinary testosterone and dihydrotestosterone concentrations were measured by radioimmunoassay ${ }^{10}$ after a separation by thin-layer chromatography. The antiserum used was specific for testosterone $(100 \%)$ and dihydrotestosterone $(66 \%)$, other compounds cross-reacting 3\% (5 $\alpha$-androstane- $3 \beta, 17 \beta$-diol $)$ or less. Thin-layer chromatography was carried out on precoated silica gel plates (Merck, 5554) in a cyclohexane:ethyl acetate (3:2) system. Serum and urinary oestradiol was measured by radioimmunoassay using a highly specific oestradiol-antiserum raised in rabbits against oestradiol-6-carboxymethyloxime-bovine serum albumin. Oestrone, oestriol, and ethinyloestradiol each cross-reacted less than $0.4 \%$ with oestradiol in the assay. For urinary oestradiol assays, a thin-layer chromatography step was included (as above but in a benzene:diethyl ether $(1: 1)$ system). The step was unnecessary for serum measurements as results were identical with or without it.

Urinary creatinine was measured by the Jaffe reaction as adapted for the AutoAnalyzer (Technicon).

To minimise methodological variance each individual hormone in serum or urine from both groups was measured in the same assay batch.

\section{Results}

\section{SERUM LEVELS}

Mean serum levels of unconjugated testosterone, dihydrotestosterone, and oestradiol in the two groups of women are shown in the table. The contraceptive group had higher mean values of both testosterone and dihydrotestosterone than the controls, and the difference was highly significant for dihydrotestosterone $(P<0.01)$. Serum oestradiol values were significantly lower in the contraceptive group $(P<0.001)$, being similar to values in postmenopausal women. Fig 1 shows the individual serum dihydrotestosterone and oestradiol values and includes values in postmenopausal women and normal men for comparison.

Mean serum levels of dihydrotestosterone and oestradiol correlated well in the normal group (fig $2 ; \mathrm{r}=0.74 ; \mathrm{P}<0.02$ ) but poorly in the contraceptive group $(r=0 \cdot 21)$. Linear correlations between serum testosterone and dihydrotestosterone and between serum testosterone and oestradiol were not significant at the $5 \%$ level in either group.

There were no differences between morning and afternoon values of the hormones in either group.

Mean $( \pm S D)$ serum and urinary levels of unconjugated testosterone, dihydrotestosterone, and oestradiol in 10 healthy women in early follicular phase of menstrual cycle and nine women on oral contraceptives. Ranges are given in parentheses

\begin{tabular}{|c|c|c|c|}
\hline & Testosterone & Dihydrotestosterone & Oestradiol \\
\hline \multicolumn{4}{|c|}{ Serum levels $(\mathrm{nmol} / \mathrm{l})$} \\
\hline $\begin{array}{l}\text { Control group } \\
\text { Contraceptive group }\end{array}$ & $\begin{array}{l}0.722 \pm 0.184 \\
(0.451-1.041) \\
0.972 \pm 0.382 \\
(0.382-1.596)\end{array}$ & $\begin{array}{l}0.313 \pm 0.145 \\
(0.082-0.616) \\
0.623 \pm 0.243 \\
(0.372-1.118)\end{array}$ & $\begin{array}{l}0.126 \pm 0.054 \\
(0.044-0.217) \\
0.038 \pm 0.012 \\
(0.022-0.051)\end{array}$ \\
\hline$t$ Test & NS & $P<0.01$ & $P<0.001$ \\
\hline \multicolumn{4}{|c|}{ Urinary excretion $(n m o l / 24 h)$} \\
\hline $\begin{array}{l}\text { Control group } \\
\text { Contraceptive group }\end{array}$ & $\begin{array}{c}320 \pm 264 \\
(115-902) \\
694 \pm 579 \\
(108-1947)\end{array}$ & \begin{tabular}{|l|}
$134 \pm 81 \cdot 2$ \\
$(36 \cdot 5-282)$ \\
$259 \pm 146$ \\
$(68 \cdot 1-488 \cdot 5)$
\end{tabular} & $\begin{array}{c}88 \cdot 1 \pm 91 \cdot 8 \\
(20 \cdot 9-274 \cdot 52) \\
25 \pm 21 \cdot 3 \\
(5 \cdot 5-73 \cdot 8)\end{array}$ \\
\hline$t$ Test & NS & $P<0.05$ & $P<0.05$ \\
\hline
\end{tabular}

NS $=$ Not significant at $5 \%$ level NS $=$ Not significant at $5 \%$ level.
Conversion: SI to traditional units-Serum testosterone: 1 nmol $/ 1 \approx 288 \mathrm{pg} / \mathrm{ml}$.
Urinary testosterone: 1 nmol/24 h $\approx 0 \cdot 288 \mathrm{pg} / 24 \mathrm{~h}$. Serum dihydrotestosterone: $1 \mathrm{nmol} / 1 \approx 290 \mathrm{pg} / \mathrm{ml}$. Urinary dihydrotestosterone: $1 \mathrm{nmol} / 24 \mathrm{~h} \approx 0.29 \mathrm{pg} / 24 \mathrm{~h}$. Serum oestradiol: $1 \mathrm{nmol} / 1 \approx 272 \mathrm{pg} / \mathrm{ml}$. Urinary oestradiol: $1 \mathrm{nmol} / 24 \mathrm{~h} \approx 0 \cdot 27$ $\mathrm{pg} / 24 \mathrm{~h}$.

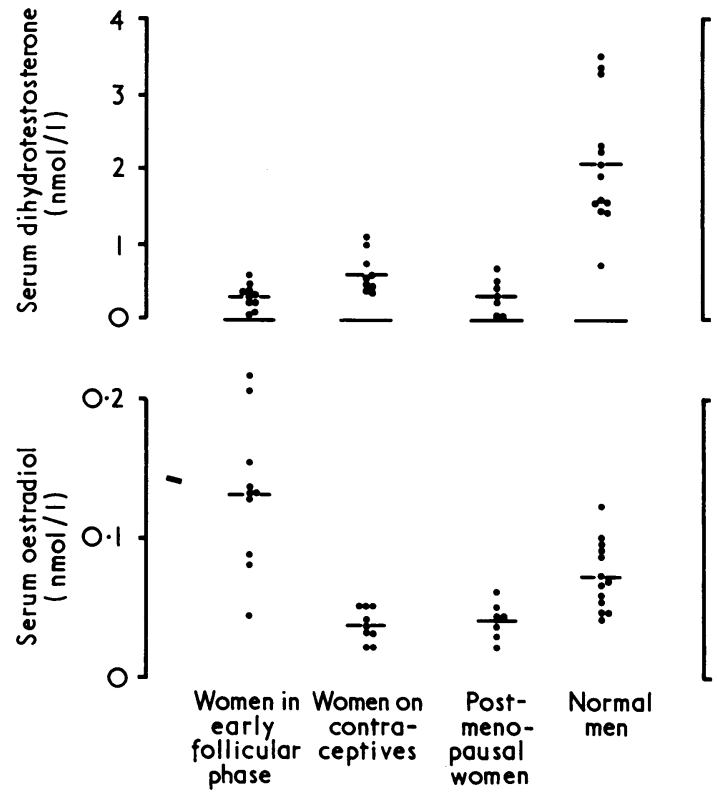

FIG 1-Serum levels (means of day and night values) of oestradiol and dihydrotestosterone in control and contraceptive groups. Levels in postmenopausal women and normal men are shown for comparison.

Conversion: SI to traditional units: Oestradiol: $1 \mathrm{nmol} / 1 \approx$ $272 \mathrm{pg} / \mathrm{ml}$. Dihydrotestosterone: $1 \mathrm{nmol} / \mathrm{l} \approx 290 \mathrm{pg} / \mathrm{ml}$.

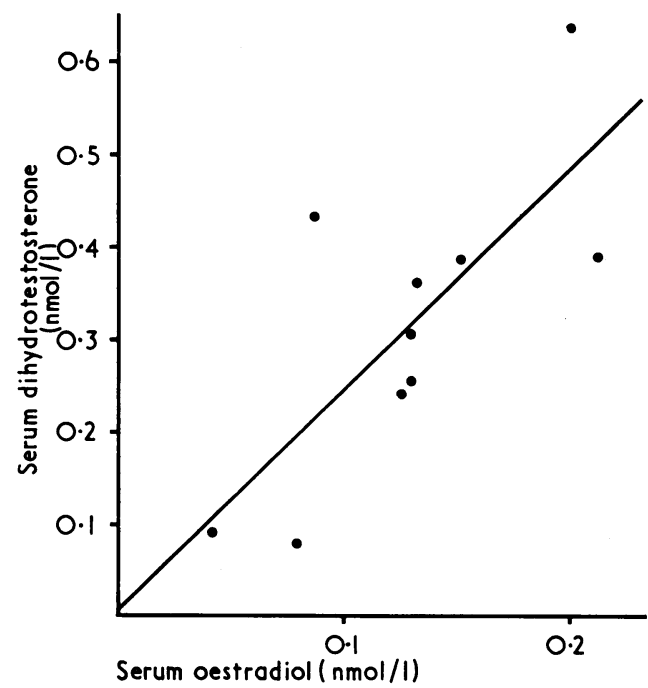

FIG 2-Relation between serum levels (means of day and night values) of dihydrotestosterone and oestradiol in the early follicular phase in 10 normal women: $y=2 \cdot 20 x$ $+0.02 ; \mathrm{r}=0.74 ; \mathrm{P}<0.02$.

\section{URINARY LEVELS}

The 24-hour urinary excretion of the unconjugated hormones is shown in the table. The contraceptive group excreted more testosterone and dihydrotestosterone than the controls, and, again, the difference was significant for dihydrotestosterone. Testosterone and dihydrotestosterone values in the night collections tended to be lower in both groups, but the values overlapped and the averages of the night and day collections were not significantly different.

The women taking contraceptives excreted less unconjugated oestradiol than the controls, and the difference between the means of the two groups was just significant. There was no difference in mean values between night and day collections.

As a check urinary creatinine excretion was measured in night and day collections from six women in each group. The average 24-hour values $( \pm S D)$ were $8.8 \pm 1.8 \mathrm{mmol} / 24 \mathrm{~h}(0.99 \pm 0.20 \mathrm{~g} / 24 \mathrm{~h})$ and $7.5 \pm 2.6 \mathrm{mmol} / 24 \mathrm{~h}(0.85 \pm 0.29 \mathrm{~g} / 24 \mathrm{~h})$ for the control and contraceptive groups respectively. 


\section{Discussion}

Our findings have shown profound changes in the endogenous sex hormone concentrations in women on oral contraceptives when compared with values in the early follicular phase of normal cycles. All changes in serum levels in the contraceptive group were corroborated by corresponding changes in the urinary excretion of the unconjugated form of each hormone.

Changes in serum dihydrotestosterone levels in the contraceptive group corresponded to the changes in testosterone concentrations. Our control serum dihydrotestosterone values were lower than those that have been reported in the normal follicular phase, ${ }^{11}{ }^{12}$ probably because all measurements in our controls were made within the first 10 days of the menstrual cycle. Some, though not all, ${ }^{13}{ }^{14}$ workers have detected small but significant changes in serum dihydrotestosterone levels during the normal menstrual cycle.

Serum oestradiol levels in our contraceptive group were reduced to the postmenopausal range. Although others have found low levels, ${ }^{45}$ they have not been this low, and the difference is probably due to differences in methods. None of the other workers used antiserum as specific for oestradiol as the one we used. Furthermore, as serum determinations with our antiserum do not need any prior chromatography step, our assay is more sensitive and can detect quantities as small as $7.5 \mathrm{pmol}(2 \mathrm{pg})$.

The different contraceptives used by our subjects produced no different effects on the sex steroid levels. As ethinyloestradiol $(50 \mu \mathrm{g})$ was the only ingredient common to all three preparations, it probably induced the hormonal changes, although the role of progestins needs further investiation.

Sex hormone binding globulin (SHBG) concentrations are raised in women taking the pill, ${ }^{15}{ }^{16}$ and it has been suggested that changes in serum SHBG concentration might influence the peripheral effects of sex hormones. ${ }^{17}$ In our contraceptive group the androgen levels increased, while oestradiol levels decreased. It is difficult to reconcile these changes with the idea, on the one hand, that they were caused by increased SHBG levels and, on the other, that changes in gonadotrophins caused the observed sex hormone changes. It is more probable that the oral contraceptives had a direct effect on steroid metabolism. This possibility is supported by the fact that oral contraceptives induce large increases in serum concentrations of the unrelated steroids cortisol and aldosterone. ${ }^{1819}$ In normal reproductive women over $95 \%$ of oestradiol comes from the ovaries, ${ }^{20}$ whereas dihydrotestosterone comes almost entirely from peripheral conversion of androstenedione and testosterone. ${ }^{21}$ Our results may therefore indicate that oral contraceptives have different effects on sex steroid synthesis in different organs.

The changes in testosterone and dihydrotestosterone levels in our contraceptive group seem to correspond with those of cortisol. ${ }^{18}$ Levels of both total and non-protein-bound unconjugated serum cortisol are increased in women on oral contraceptives, and serum non-protein-bound cortisol levels correlate well with the urinary excretion of the unconjugated cortisol. ${ }^{22}$ In another study we also found a significant correlation between unconjugated testosterone and dihydrotestosterone and urinary creatinine in normal men and women, ${ }^{23}$ which suggests that glomerular filtration may be the main renal excretory mechanism for the unconjugated hormones.

The increased urinary excretion of unconjugated androgens by women taking contraceptives suggests that they have an increased level in circulating "tissue-available" androgens. As symptoms of virilism do not occur in women on the pill despite their increased exposure to the two most potent naturally occurring androgens ${ }^{8}$ the contraceptives themselves must block their effects-that is, they must have a peripheral antiandrogenic effect.

The significant positive correlation between the serum dihydrotestosterone and oestradiol levels in the control group suggests the existence of an inherent balance in the body between these two hormones. Such a balance may also be inferred from animal experiments showing a synergistic effect between the hormones when administered. ${ }^{24}{ }^{25}$ The absence of this correlation in those taking contraceptives might indicate that oral contraceptives act by destroying that balance.

The raised serum testosterone levels in women taking contraceptives contrast with the reduced levels found in men after ethinyloestradiol administration. ${ }^{26}{ }^{27}$ This opposite response in the two sexes is probably related to differences in sex hormone metabolism. The conflicting reports on the effects of oral contraceptives on serum testosterone levels in hirsute women ${ }^{728}$ might mean that these patients show varying degrees of "malelike" responses.

The antiovulatory effects of the oral contraceptives are probably related to the changes they induce in sex hormone levels. Thus low serum oestradiol levels preclude oestradiol's positive feedback action on the pituitary release of gonadotrophins, ${ }^{29}$ and the increased androgen levels would tend to inhibit the hypothalamus. More significantly, however, the low serum oestradiol levels indicate low oestradiol production and intraovarian oestradiol levels, and the ovary itself is likely to be the primary target of the contraceptive, although there has been no study on the effects of oral contraception on oestradiol production by ovarian tissue.

The dihydrotestosterone:oestradiol ratio in the contraceptive group was over six times higher than that in the normal group. Further study might show whether this ratio could be used as an index of the antiovulatory efficiency of contraceptive preparations.

We thank $\operatorname{Dr} \mathrm{E}$ Youssefnejadian, Institute of Obstetrics and Gynaecology, Chelsea Hospital for Women, London, for the oestradiol antiserum.

This work was supported by grants from the Kishinchand Chellaram Foundation and the Cancer Research Campaign to GFJ.

\section{References}

${ }^{1}$ Briggs, $\mathrm{M} \mathrm{H}$, et al, Advances in Steroid Biochemistry and Pharmacology, $1970,2,111$

${ }^{2}$ Mishell, D R, et al, American fournal of Obstetrics and Gynecology, 1972, 114, 923.

${ }^{3}$ Briggs, M H, and Briggs, M, fournal of Obstetrics and Gynaecology of the British Commonwealth, 1972, 79, 946.

4 Johansson, E D B, Boilert, B, and Gemzell, C, in Gonadotrophins, ed B B Saxena, C G Beling, and H M Gandy, p 758. London, Wiley, 1972.

${ }^{5}$ Johansson, E D B, Acta Obstetricia et Gynecologica Scandinavica, 1975, $54,217$.

6 Tremblay, R R, and Dube, J Y, Contraception, 1974, 10, 599.

7 Easterling, W E, jun, Talbert, L M, and Potter, H D, American fournal of Obstetrics and Gynecology, 1974, 120, 385.

${ }^{8}$ Liao, S, and Fang, S, Vitamins and Hormones, 1969, 27, 17.

${ }^{9}$ Burke, C W, et al, Quarterly fournal of Medicine, 1973, 42, 693.

${ }_{10}$ Kjeld, J M, et al, Acta Endocrinologica, 1976, 81, 234.

${ }_{11}$ Barberia, J M, and Thorneycroft, I H, Steroids, 1974, 23, 757.

12 Vermeulen, A, and Verdonck, L, American fournal of Obstetrics and Gynecology, 1976, 125, 491.

13 Abraham, G E, Fournal of Clinical Endocrinology and Metabolism, 1974, 39, 340 .

14 Guerrero, R, et al, Acta Endocrinologica, 1976, 81, 133.

15 Briggs, M H, Contraception, 1975, 12, 149

16 van Kammen, E, et al, Contraception, 1975, 11, 53.

17 Anderson, D C, Clinical Endocrinology, 1974, 3, 69.

18 Burke, C W, Fournal of Clinical Pathology, 1970, 23, Suppl No 3, p 11.

19 Beckerhoff, $\mathrm{R}$, et al, Lancet, 1973, 1, 1218.

20 Baird, D T, and Fraser, I S, fournal of Clinical Endocrinology and Metabolism, 1974, 38, 1009.

21 Ito, T, and Horton, R, fournal of Clinical Investigation, 1971, 50, 1612.

${ }^{22}$ Burke, C W, and Beardwell, C G, Quarterly fournal of Medicine, 1973, 42, 175.

${ }^{23}$ Kjeld, J M, Puah, C M, and Joplin, G F, unpublished.

24 Larsen, K, Sodersten, P, and Beyer, C, Fournal of Endocrinology, 1973, 57, 563.

${ }^{25}$ Palmiter, R D, and Haines, M E, fournal of Biological Chemistry, 1973, 248, 2107.

${ }^{26}$ Clarke, A F, et al, Clinical Endocrinology, 1973, 2, 361.

27 Forchielli, E, et al, Acta Endocrinologica, 1965, 50, 51.

28 Givens, J R, et al, American fournal of Obstetrics and Gynecology, 1976, 124, 333 .

29 Jaffe, R B, and Keye, W R, fournal of Steroid Biochemistry, 1975, 6, 1055. 